work by Dr. la Cour, Copenhagen, and will supply the standard and special quick-run traces respectively. By running a third set of variometers at low sensitivity it is hoped to ensure that even in the biggest perturbations of the field during magnetic disturbance no trace will be lost. The provision of a double set of absolute instruments is intended not to cater for emergencies alone; the present Fort Rae, which will be the main base of the expedition, is some seventeen miles farther up the north arm of the Great Slave Lake than the settlement of fifty years ago. For such purposes as establishing the secular change in the magnetic elements it will therefore be necessary to carry out sets of parallel observations at this subsidiary station.

The necessity for occasional occupation of the old Fort Rae site will be turned to further useful account by equipping the sledge party which will travel there in the winter months with a spare auroral camera, and by having some means of communication between the two bases. In this way it is hoped to use the two posts as base line stations for photography of aurora, and so to provide data for determining its height by the well-known methods developed by Prof. Störmer. It is of interest to observe in this connexion that, so far as is known, Fort Rae is very near to the zone of maximum frequency of aurora.

These three fields of meteorology, terrestrial magnetism, and aurora constitute the primary work of all the Polar Year stations, but, in addition, the party at Fort Rae hopes to obtain very complete information regarding the atmospheric electrical and allied phenomena of the region. Using a Benndorf electrograph, continuous records of the potential gradient of the earth's electric field will be kept; and equipment will be taken to observe, whenever opportunity allows, the conductivity of the air and the air-earth current using a modified Wilson electrometer, the small ion content of the air using a modified Ebert apparatus, the nucleus content with the standard Aitken instrument, and, if possible, the rate of production of atmospheric ionisation with an apparatus specially designed at Kew Observatory.

The Fort Rae party will consist of six men under the leadership of Mr. J. M. Stagg of the Meteorological Office. They will leave England about the middle of May of this year and proceed via Montreal to Edmonton. North of Edmonton the route will lie down the River Athabasca to the lake of that name, and then down the Slave River, past the seventeen miles of rapids between Fitzgerald and Fort Smith, to Fort Resolution on the south side of the Great Slave Lake, thence across the body of the lake and up the north arm nearly to its most northern extremity. This should be reached by the third week in June, thus giving time to erect the special non-magnetic huts required for the absolute observations and continuous registration of the magnetic field and instal the instrumental equipment in readiness for the official starting date of the Second Polar Year on Aug. 1. The party will continue observing until as late in August 1933 as may be safely done without undue risk of being frozen in for the next winter.

\title{
The Drumm Traction Battery
}

\section{By Prof. A. J. Allmand, F.R.S.}

W IDE interest has recently been aroused by reports of the successful trials of an electric train propelled by a Drumm transport battery, as also by certain details concerning the battery itself which have been made public. During the last two years I have had ample opportunity of examining and experimenting with the Drumm cell at various stages of its evolution, and it seems desirable now to put on record a statement of its main electrochemical features.

It is an alkaline cell, and the only metals which enter into its construction are stainless steel, pure nickel, and, at present, nickelled steel. Its mechanical strength and so forth are correspondingly satisfactory. As in other successful alkaline batteries, the positive plate system consists of the $\mathrm{Ni}(\mathrm{OH})_{2}$ $-\mathrm{Ni}(\mathrm{OH})_{3}$ mixture first developed by Edison; several types of such positives have been employed. Whereas, however, in other cells, the negative plate system is essentially $\mathrm{Fe}-\mathrm{Fe}(\mathrm{OH})_{2}$, it consists of $\mathrm{Zn}-\mathrm{Zn}(\mathrm{OH})_{2}$ in the Drumm battery. Moreover, $\mathrm{Zn}(\mathrm{OH})_{2}$ is soluble in alkali, whilst $\mathrm{Fe}(\mathrm{OH})_{2}$ is not. Consequently, instead of containing a solid hydroxide which becomes reduced to metal on charge, the Drumm negatives consist of nickel gauze grids, immersed in the solution of zinc oxide in potash constituting the electrolyte, and these on charge become coated with metallic zinc. The cell reactions in this 'zine' accumulator, written in their simplest form, are consequently

$$
2 \mathrm{NiO}+\mathrm{HZnO}_{2}^{\prime} \underset{\text { Discharge }}{\stackrel{\text { Charge }}{\longrightarrow}} \mathrm{Ni}_{2} \mathrm{O}_{3}+\mathrm{Zn}+\mathrm{OH}^{\prime}
$$

as compared with

$$
2 \mathrm{NiO}+\mathrm{FeO} \underset{\text { Discharge }}{\stackrel{\text { Charge }}{\rightleftarrows}} \mathrm{Ni}_{2} \mathrm{O}_{3}+\mathrm{Fe}
$$

in the 'iron' accumulator.

One feature of such a cell will be immediately obvious. Owing to the relative positions of zine and of iron in the electrochemical series, its voltage will be unusually high for an alkaline cell. Depending somewhat on the part of the positive discharge curve used in practice, the average figure under normal conditions for the fully charged cell is about 1.86 volts, as compared with about 1.34 volts for the iron accumulator. The forty per cent increase represents a considerable advance. This is important, but the main advantage claimed by the inventor, which would seem to put the cell in a class of its own amongst transport batteries, depends on facts of quite a different nature.

No. 3254, VoL. 129] 
Briefly, whilst the two electrode processes $\mathrm{Fe}+$ $2 \theta \rightleftarrows \mathrm{Fe}$ are subject to considerable irreversible effects, which limit the maximum practicable current densities to relatively low figures, this is not the case with the electrode processes $\mathrm{Zn}+2 \theta \underset{\mathrm{Zn}}{\longleftrightarrow \text {. }}$ There is no need to emphasise a point known to all. Iron is a metal which becomes passive with notorious ease when used as anode, and the work of Foerster has demonstrated the existence of important retardation effects during its cathodic deposition. Zinc, on the other hand, dissolves freely on anodic polarisation, as in many types of primary cell, and very high current densities are known to be used successfully in its technical electro-deposition. As a result, far heavier currents can be put through a $\mathrm{Zn} / \mathrm{Zn}$ than through a $\mathrm{Fe} / \mathrm{Fe}$ electrode, during both charge and discharge. The properties of the $\mathrm{NiO} / \mathrm{Ni}_{2} \mathrm{O}_{3}$ electrode are sufficiently good from the same point of view with the consequence that the Drumm battery, which combines these two electrode systems, can both be charged and discharged at abnormally high rates. The standard rate of charging of a single technical cell of total weight $112 \mathrm{lb}$., allowing for all losses in efficiency, corresponds to an input of $0 \cdot 134$ effective watthour/Ib./minute, about four times the rate normal to other alkaline batteries. In practice, the same cell is normally discharged at a current of 400 amperes and an average voltage of 1.65 volts, equivalent to practically $0 \cdot 1$ watt-hour $/ \mathrm{lb}$. /minute. This itself is twice the highest discharge rate recommended for other alkaline batteries. But, over and above this, the current can, when required, be raised to 1000 amperes for limited periods, corresponding to an energy delivery of about 0.22 watt-hour/lb. minute-a very high figure indeed. The cell deals with these heavy loads quite comfortably, with no sign of deterioration.

The power of furnishing energy at these unprecedented rates makes it possible for a traction battery of Drumm cells to overcome the grave disadvantage inherent in the majority of such batteries, namely, the impossibility of furnishing rapid accelerations. The train now operating between Dublin and Bray can accelerate from a standstill at about 1 mile per hour per second, attain speeds of 40-50 miles an hour with ease, and is provided with a successful system of regenerative braking, whereby an important fraction of the energy surge made available on a down-gradient or on decelerating at a station is returned to the battery.

There is one further very important matter. The specific watt-hour capacity of the Drumm cell on a single charge is not particularly high. In fact, in the case of the battery especially designed for the above train, it is very low-perhaps 15 per cent of that of an iron battery. But its capacity for high loads enables this battery to be charged at the termini and afterwards discharged many times during the working day; probably twenty such charges will be standard when in full operation. Consequently, the daily work of which unit weight of battery is capable will be, not 15 per cent, but 300 per cent of the normal-a fact naturally of prime importance when considering initial costs, quite apart from the elimination of the expense of an all-night charge.

With regard to other practical points, the cell possesses to a high degree the virtues of simplicity of construction and of operation, whilst there are definite grounds, which I am not at liberty to mention, for anticipating a long life. Neither overcharge, nor overdischarge, nor long idle periods have any ill effect of importance. Self-discharge is exceedingly low.

A few electro-chemical details may be added in conclusion. Under standard working conditions, the average current efficiency is $92-93$ per cent, the concordant result of long-continued tests on cells of varying capacity. The average voltage during charge and discharge is 2.03 and 1.65 respectively. The energy efficiency is therefore practically 75 per cent. These are favourable figures, and strikingly so when it is remembered for what high loads they hold good ; they also connote relatively small gassing and low temperature rise. During the greater part of both charge and discharge periods, the polarisation alters linearly with time. Investigation shows this change to be due almost entirely to the positive plate. The polarisation at the negative is considerably less than at the positive, and scarcely alters with time (unless the cell be overdischarged). Of the total voltage losses in a cycle, roughly half is associated with the positive, and one-quarter each with the negative and the electrolyte. The exact concentrations of caustic potash and of zinc oxide in the latter vary in accordance with the purpose for which the cell is designed, and there is no point in giving detailed figures. The essential points are, of course, an electrolyte of high conductivity and sufficient dissolved zinc oxide for the operating conditions.

It is clear that Dr. Drumm has produced a cell of somewhat remarkable properties, and that, although primarily designed for transport purposes, these properties may lead to its utilisation in other fields.

\section{Adsorption of Gases}

$\mathrm{T}^{\mathrm{H}}$ HE recent discussion held by the Faraday Society at Oxford, on Jan. 12-13, was devoted to a consideration of the problems connected with the adsorption of gases. The general introduction was given by Prof. H. S. Taylor of Princeton University, and a number of distinguished foreign guests presented their communications in person, including Prof. A. Magnus of Frankfort, Prof. A. F. Benton of Virginia, Prof. E. Huckel of
Stuttgart, Dr. A. Farkas of Frankfort, and Drs. H. Dohse and Schuster of Ludwigshafen. The attention of the meeting was devoted almost exclusively to two important considerations, types of adsorption and discontinuities in adsorption processes.

A study of the chemical behaviour of adsorbed molecules as well as the great difference in the heats of adsorption of gases on substances such as silica 